\title{
Efficiency of blood "refreshing" method in cattle pure breeding of the Simmental breed
}

\author{
Sergey Aleksandrovich Lamonov*, Irina Alekseevna Skorkina \\ Michurinsk State Agrarian University
}

\begin{abstract}
Over the past two decades, pedigree cattle and sperm products have been imported into the Russian Federation from outstanding breeding bulls of the Simmental breed from Western Europe, including Austria, within the framework of the "AIC Development" national project. Specific productive and technological qualities are inherent in these animals due to the direction peculiarities of selection and breeding work with this breed in Austria. World experience has clearly proved that the future belongs to large dairy complexes and farms, which are fully mechanized and automated. Modern Simmental cattle (mostly cows) do not meet the requirements of intensive milk production technology for a number of productive and technological characteristics. Summarizing the world zootechnical experience, it is possible to determine the basic requirements for cows suitable for operation in conditions of advanced milk production technologies. Based on numerous studies, these animals are characterized by high milk production, good reproductive qualities, suitable for machine milking, with strong hoof horn, resistant to diseases and mastitis. Consequently, a significant role is given to the manning of a milking herd with highly productive and competitive Simmental cows, obtained as a result of improving the system of selection and breeding work to further increase the production of marketable milk. The conducted research result shows zootechnical efficiency of using such a breeding method as "refreshing" blood in the breeding process. In particular, the best indicators of milk yield for the first lactation are observed in cows descended from bullsproducers of Austrian selection, $-4153.1 \mathrm{~kg}$ of natural fat milk. The morphological and functional characteristics of the udders of all experimental first-calf cows meet the requirements of suitability for machine milking. Cows of the Simmental breed obtained by the method of "blood refreshing" are the most cost-effective in the same conditions of feeding and keeping.
\end{abstract}

\section{Introduction}

Further intensification of domestic dairy cattle breeding directly depends on the effectiveness of selection and breeding work to improve the Simmental breed through the rational use of the world gene pool $[3,6,7]$.

It has been proven that long-term breeding of animals even in distant degrees of kinship, as well as mating obtained by long-term use of the same breeding method, sometimes leads to inbred depression - a constitution weakening and a decrease in milk productivity and reproductive capacity. It is recommended to use blood "refreshing" to eliminate these undesirable phenomena. $[1,2,4]$.

This method is carried out by using bulls-producers of the same breed, but received from different climatic conditions or from another country [1]. There is insufficient data on the study of economic and biological characteristics of Simmental cattle received by the given breeding method. Evaluation of the productive and technological qualities of Simmental cows of various origins in the same conditions of feeding, maintenance and service, and the identification of the most promising genotypes is of great significance for purposeful selection and breeding work $[4,6,8,10]$. This is the purpose of our research. Therefore, the study of the effective use of cows of domestic and Austrian selection in milk production is relevant.

\section{Materials and research methods}

We carried out a comparative assessment of main economic and biological characteristics of purebred Simmental cows of domestic selection and Simmental cows obtained from bulls-producers of the Holstein breed of red-and-white color and the Simmental breed of Austrian selection. Groups of animals were formed from heifers (6-8 months of gestation) according to the principle of paired analogs, taking into account the age of experimental animals, their live weight and milk productivity of mothers for the first lactation, guided by the generally accepted method of conducting zootechnical experiments.

The first group included purebred Simmental animals of domestic selection (SDS), second - Simmental Holstein hybrids (SDxCHH), and third - individuals

* Corresponding author: ivan0068@bk.ru 
obtained from cows of the Simmental breed of domestic selection and bulls of Austrian selection (SSAS). Mothers of heifers in all groups were purebred Simmental cows with fairly similar milk production rates (from 4500 to $5000 \mathrm{~kg}$ of milk).

The main background, which underwent a comparative assessment of first-calf cows of various genotypic groups in terms of economic and biological characteristics, included the same conditions of housing, feeding and maintenance. This contributed to a more complete manifestation of genetic characteristics of the experimental animals. The experimental animals were observed from the moment of calving until the end of the first lactation.

\section{Research results and their analysis}

Studies have shown that two interrelated processes - the growth of an animal and its development simultaneously occur in the process of ontogenesis in a young organism. The patterns of growth and development, as well as the influence of various paratypical factors, and above all, feeding, were established in the papers of many zootechnician scientists $[3,5,9]$. Their studies prove the possibility of managing the growth and development of young animals by changing the level of feeding at diverse stages of individual growth and housing conditions.

Analyzing the data concerning the dynamics of the heifers live weight of different genotypic groups (Table 1 ), we have found that representatives of the $\mathrm{SDxCHH}$ group have the best indicators. The difference in live weight at birth was $2.3-2.5 \mathrm{~kg}(\mathrm{P}>0.95)$ compared to individuals in the SDS and SSAS groups. By 18 months of age, heifers in the SDxCHH group - $345.5 \mathrm{~kg}$ and heifers in the SSAS group - $334 \mathrm{~kg}$ have the best live weight indicators.

Unfortunately, the feeding conditions did not allow achieving best results, therefore the first insemination age of animals in all experimental groups was later than necessary (Table 2). Heifers in the SDxCHH group were inseminated earlier than others - at 20.8 months, and the later age of the first insemination was noted in the SDS group - at 23.2 months.

It is possible to judge not only the type of physique by the totality of separate body measurements, but also the direction of the animal productivity. In this regard, great importance was attached to the assessment of animals on the exterior (Table 3 ).

Comparing the data on body measurements of experimental first-calf heifers of the Simmental breed, we noted an explicit superiority of individuals in the $\mathrm{SDxCHH}$ group over representatives of other groups by height at withers for 4,4-4,8 cm, chest depth $-2,1-3,6$ $\mathrm{cm}$, chest width $-2,9 \mathrm{~cm}$. Significant differences between groups were not revealed for other body measurements, such as oblique body length, pastern girth, and width in hips. Physique indices calculated on the basis of these measurements showed that animals in the SDxCHH group, as well as first-calf cows in the SDS and SSAS groups, tended to have a dairy-meat body type.

Table 1. Dynamics of live weight of experimental heifers, $\mathrm{kg}$

\begin{tabular}{|c|c|c|c|}
\hline Age, month. & SSAS & SDxCHH & SDS \\
\hline $\mathrm{n}$ & 10 & 10 & $29,9 \pm 1,7$ \\
\hline At birth & $29,5 \pm 1,7$ & $32,2^{\mathrm{x}} \pm 2,8$ & $126,6 \pm 3,6$ \\
\hline 6 & $124,0 \pm 3,5$ & $190,3^{\mathrm{x}} \pm 8,8$ & $193,5 \pm 4,4$ \\
\hline 10 & $185,6 \pm 4,3$ & $197,2^{\mathrm{x}} \pm 8,3$ & $219,0 \pm 4,7$ \\
\hline 12 & $219,3 \pm 4,7$ & $224,2^{\mathrm{x}} \pm 8,5$ & $324,1 \pm 5,7$ \\
\hline 18 & $334,0 \pm 5,8$ & $345,5^{\mathrm{x}} \pm 9,6$ & \\
\hline
\end{tabular}

Note: ${ }^{\mathrm{x}}-\mathrm{P}>0,95$.

Table 2. Age and live weight at the first insemination of heifers and calving heifers, and first-calf cows of various genotypic groups

\begin{tabular}{|c|c|c|c|c|c|c|}
\hline $\begin{array}{c}\text { Group of } \\
\text { animals }\end{array}$ & $\mathrm{n}$ & $\begin{array}{c}\text { Age of first } \\
\text { insemination, } \\
\text { months. }\end{array}$ & $\begin{array}{c}\text { Live weight at first } \\
\text { insemination, } \mathrm{kg}\end{array}$ & $\begin{array}{c}\text { Age at first } \\
\text { calving, } \\
\text { months. }\end{array}$ & $\begin{array}{c}\text { Live weight } \\
\text { before first } \\
\text { calving, } \mathrm{kg}\end{array}$ & $\begin{array}{c}\text { Live weight } \\
\text { after first } \\
\text { calving, } \mathrm{kg}\end{array}$ \\
\hline SDS & 10 & $23,2 \pm 1,52$ & $379,0 \pm 6,15$ & $32,2 \pm 1,8$ & $496,5 \pm 5,3$ & $445,1 \pm 5,7$ \\
\hline SSAS & 10 & $22,7 \pm 1,50$ & $376,6 \pm 6,13$ & $31,7 \pm 1,71$ & $489,4 \pm 4,4$ & $437,3 \pm 4,7$ \\
\hline SDxCHH & 10 & $20,8^{\mathrm{x}} \pm 1,80$ & $383,5^{\mathrm{x}} \pm 11,6$ & $29,8^{\mathrm{x}} \pm 2,31$ & $509,3^{\mathrm{x}} \pm 5,4$ & $467,7^{\mathrm{x}} \pm 10,1$ \\
\hline
\end{tabular}

Note: ${ }^{\mathrm{x}}-\mathrm{P}>0,95$ 
Table 3. Measurements of basic exterior items and physique indices of the experimental first-calf cows of the Simmental breed

\begin{tabular}{|l|c|c|c|}
\hline \multicolumn{1}{|c|}{ Indicators } & SDS & SDxCHH & SSAS \\
\hline Measurements, cm & $129,7 \pm 3,6$ & $134,5^{\times} \pm 3,6$ & $130,1 \pm 3,6$ \\
\hline Height at withers & $134,3 \pm 3,7$ & $136,3^{\times} \pm 3,7$ & $134,4 \pm 3,6$ \\
\hline Rump height & $65,0 \pm 2,5$ & $68,6^{\times} \pm 2,5$ & $66,5 \pm 2,5$ \\
\hline Chest depth & $45,2 \pm 2,1$ & $46,6 \pm 2,2$ & $45,2 \pm 2,1$ \\
\hline Chest width & $147,3 \pm 3,8$ & $146,4 \pm 3,7$ & $147,7 \pm 3,7$ \\
\hline Oblique body length & $194,1 \pm 4,4$ & $196,0^{\times} \pm 4,5$ & $194,1 \pm 4,1$ \\
\hline Chest girth & $19,8 \pm 1,4$ & $19,0 \pm 1,4$ & $19,0 \pm 1,3$ \\
\hline Pastern girth & $48,1 \pm 2,2$ & $49,2 \pm 2,2$ & $48,8 \pm 1,7$ \\
\hline Width in hips & $19,0 \pm 1,4$ & $19,7 \pm 1,4$ & $19,9 \pm 1,1$ \\
\hline $\begin{array}{l}\text { Width at ischial } \\
\text { tuberosities }\end{array}$ & 49,8 & \multicolumn{2}{|c|}{} \\
\hline Physique indices, \% & 113,6 & 48,9 & 48,9 \\
\hline Long legs & 69,5 & 108,8 & 113,5 \\
\hline Lengthiness & 103,5 & 101,3 & 67,9 \\
\hline Pectoral & 253,2 & 249,7 & 103,3 \\
\hline Overmaturity & 131,8 & 133,9 & 245,2 \\
\hline Narrow quarters & 15,3 & 14,1 & 131,4 \\
\hline Blockiness (compactness) & 93,9 & 94,7 & 92,6 \\
\hline Boniness & 149,6 & 147,9 & 149,2 \\
\hline Pelvic-chest & \multicolumn{3}{|l}{} \\
\hline Massiveness & \multicolumn{3}{|c|}{} \\
\hline
\end{tabular}

Note: ${ }^{\mathrm{x}}$ - P>0,95

The comparative analysis results of milk productivity in the groups of experimental first-calf cows demonstrated that there were certain intergroup differences in the first lactation duration (Table 4). First- calf cows of the SSAS group had a longer lactation than their purebred counterparts of domestic breeding (SDS) by 11,7 days, and by 10,1 days than hybrid first-calf cows from the SDxCHH group.

Table 4. Milk productivity of experimental first-calf cows of the Simmental breed

\begin{tabular}{|c|c|c|c|}
\hline \multirow[t]{2}{*}{ Indicators } & \multicolumn{3}{|c|}{ Group of animals } \\
\hline & SDS & $\mathrm{SDxCHH}$ & SSAS \\
\hline $\mathrm{n}$ & 10 & 10 & 10 \\
\hline Number of milking days & $259,9 \pm 4,6$ & $261,5 \pm 8,0$ & $271,6 \pm 7,9$ \\
\hline Milk yield, $\mathrm{kg}$ & $3226,9 \pm 149,2$ & $3355,1 \pm 221,1$ & $4153,1^{x x} \pm 262,8$ \\
\hline MFF (Mass fraction of fat), $\%$ & $3,78 \pm 0,02$ & $3,74 \pm 0,02$ & $3,77 \pm 0,01$ \\
\hline Amount of milk fat, $\mathrm{kg}$ & $122,3 \pm 5,7$ & $129,2 \pm 8,8$ & $156,6^{\mathrm{xx}} \pm 9,9$ \\
\hline
\end{tabular}

Note: ${ }^{\mathrm{x}}-\mathrm{P}>0,99$

In turn, the lactation of first-calf cows, originating from bulls-producers of Austrian selection (SSAS), was 1.6 days longer than first-calf cows of domestic selection (SDS).

It should be noted that first-calf cows in the SSAS group were the most abundant in milk. Thus, the first lactation averaged $4153.1 \mathrm{~kg}$ of natural fat milk, which is $926.2 \mathrm{~kg}$ more than from first-calf cows of domestic selection (SDS) at $\mathrm{P}>0.99$, and $798.0 \mathrm{~kg}$ more than from first-calf cows descended from bulls-producers of the Holstein breed of red-and-white color (SDxCHH) at $\mathrm{P}>0.99$. Crossbred cows turned out to be the best in milk yield among first-calf cows in the other two groups (SDxCHH) - $128.2 \mathrm{~kg}$ more milk than purebred domestic breeding cows. The highest fat content in milk was noted in first-calf cows of domestic breeding - $3.78 \%$ on average, which is $0.01-0.04 \%$ more than animals from the SSAS and SDxCHH experimental groups, respectively.

Analysis of the lactation nature of first-calf cows of the compared genotypic groups is of special practical and theoretical interest. It makes it possible to supplement the economic and biological assessment of animals by milk production, on the basis of which it seems to be possible to predict the subsequent milk production of cows.

The indicator of lactation completeness was calculated using the Veselovsky-Shaposhnikov method to characterize the course of lactation in experimental cows (Table 5).

The completeness indicator of lactation according to the Veselovsky-Shaposhnikov method reflects the distribution nature of milk yield throughout lactation.

\footnotetext{
*Corresponding author: ivan0068@bk.ru
} 
Table 5. Completeness lactation indicators of experimental first-calf cows of the Simmental breed, \%

\begin{tabular}{|c|c|}
\hline Group of animals & $\begin{array}{c}\text { Completeness indicator of lactation for the first } \\
\text { lactation, } \%\end{array}$ \\
\hline SDS & 79,3 \\
\hline SDxCHH & 82,3 \\
\hline SSAS & 82,9 \\
\hline
\end{tabular}

The best indicators were noted in first-calf heifers of the genotypic group (SSAS) - 82.9\%, but this difference between the groups is insignificant. In all cases, the calculated indicator of the lactation usefulness pointed that the animals of the compared genotypic groups had stable and even lactation.

The morphological and functional assessment of the udder of cows is one of the essential measures of technological selection and is carried out in order to determine the suitability for machine milking. Many zootechnician-scientists have proven that udder quality takes the second place among the selection traits after lactation; this quality is determined by morphological and functional indicators (shapes of the udder and nipples, their measurements, duration of milking, intensity of milk flow, etc.) $[1,4,7]$.

It was found that cows of different genotype groups had the best udder shape - bowl-shaped (60-70\% of individuals). Besides, the cylindrical shape of the nipples was predominant ( $80 \%$ of individuals).

We noted the advantage of first-calf cows in the SSAS and SDxCHH genotypic groups in terms of the udder morphological parameters in comparison with first-calf cows from the group (SDS) of the Simmental breed of domestic selection. They exceeded in udder girth by $7.9 \mathrm{~cm}$ and $8.3 \mathrm{~cm}$, udder length - by $2.7 \mathrm{~cm}$ and $4.1 \mathrm{~cm}$, udder depth - by $4.4 \mathrm{~cm}$, respectively.

Essential technological properties of the udder include nipple size and their placement. The best nipple placement was noted in first-calf cows in the SDxCHH genotypic group. A closer position of nipples was recorded in Simmental first-calf cows of domestic breeding (SDS), but the difference between the groups is statistically insignificant.

Selection of cows for machine milking suitability is based not only on the assessment of the udder morphological characteristics, but on the assessment of its functional peculiarities. We have studied such functional characteristics of the cow udders as the milking duration and milk production intensity (Table 6).

The duration of milking depends on the type of milking machine, the frequency of milking, the intensity (speed) of milk flow, and individual characteristics of the cow. The productivity of milking installations and the labor of service personnel depend on the duration of milking, as well as the completeness of milking. It is significant to empty the udder as soon as possible due to the short-term effect of oxytocin - within 4-5 minutes. If the lactation intensity is high, then the milking process takes less time.

Table 6. Functional properties of the udder of experimental first-calf cows of the Simmental breed

\begin{tabular}{|c|c|c|c|c|}
\hline Group of animals & $\mathrm{n}$ & $\begin{array}{c}\text { Single milk } \\
\text { yield, kg }\end{array}$ & $\begin{array}{c}\text { Milking } \\
\text { duration, min }\end{array}$ & $\begin{array}{c}\text { Milk flow } \\
\text { intensity, } \mathrm{kg} / \mathrm{min}\end{array}$ \\
\hline SDS & 10 & $7,3 \pm 0,4$ & $6,7 \pm 0,2$ & $1,1 \pm 0,06$ \\
\hline SDXCHH & 10 & $8,4 \pm 0,5$ & $7,3 \pm 0,3$ & $1,2 \pm 0,04$ \\
\hline SSAS & 10 & $9,5 \pm 0,6$ & $8,1 \pm 0,3$ & $1,2 \pm 0,05$ \\
\hline
\end{tabular}

First-calf cows in the SSAS and SDxCHH groups had an advantage in milk yield by $0.1 \mathrm{~kg} / \mathrm{min}$, but the obtained difference in this indicator between genotypic groups is statistically insignificant.

The analysis of the above data shows that the udder of first-calf cows in the experimental groups meets the requirements for suitability of the Simmental cows for machine milking in terms of their morphological and functional characteristics.

The comparative assessment of reproductive qualities of experimental first-calf cows of diverse genotypic groups is of great practical and theoretical significance in order to identify the most optimal genotype, which successfully combines high milk productivity with good reproductive qualities in the current economic conditions of feeding, maintenance and service (Table 7).

In the course of the experiment, it was revealed that the shortest duration of the service period was observed in the group of first-calf cows of domestic selection (SDS) - 56.6 days on average. This indicator was slightly higher in animals of the SDxCHH and SSAS genotypic groups, by 2.3 and 2.9 days, respectively (difference is not statistically significant).

The gestation duration in heifers was within the normal range: from 279.1 to 281.4 days. The insemination index of various genotypic groups was also within the normal range from 1.3 to 1.4 .

Fertility from the first insemination was good in young animals - within $60-70 \%$. A higher fertilization rate from the first insemination - by $10 \%$ was noted in the genotypic group of the Simmental breed of domestic selection (SDS).

The heaviest litter was obtained from animals in the SDxCHH and SSAS genotypic groups in comparison with heifers of domestic selection (SDS), by 2.2 and 2.5 $\mathrm{kg}$, respectively.

The economic efficiency of using Simmental cows of different genotypic groups for milk production was determined by the accounting method for supplementary revenue obtained from the milk sale of basic fat content. 
The economic efficiency assessment, used for the milk production of the Simmental cows of various genotypic groups, showed that the Simmental cows obtained by the "blood refreshing" method turned out to be the most cost-effective under the same conditions of feeding and keeping (Table 8).
These first-calf cows exceeded their counterparts in the amount of base fat milk in the other two genotypic groups by $4,6-27,6 \%$, and in terms of the cost of additional produced milk by $14,535-87,188$ rubles.

Table 7. Reproductive qualities in various genotypic groups of first-calf cows

\begin{tabular}{|c|c|c|c|c|c|c|c|c|}
\hline \multirow{2}{*}{$\begin{array}{c}\text { Group of } \\
\text { animals }\end{array}$} & \multirow{2}{*}{$\mathrm{n}$} & \multirow{2}{*}{$\begin{array}{c}\text { Service- } \\
\text { period, day }\end{array}$} & \multirow{2}{*}{$\begin{array}{l}\text { Duration of } \\
\text { gestation, } \\
\text { day }\end{array}$} & \multirow{2}{*}{$\begin{array}{l}\text { Live weight } \\
\text { of litter, kg }\end{array}$} & \multirow{2}{*}{$\begin{array}{l}\text { Inseminati } \\
\text { on index }\end{array}$} & \multirow{2}{*}{$\begin{array}{c}\text { Fertility from first } \\
\text { insemination, } \\
\%\end{array}$} & \multicolumn{2}{|c|}{ Number of calves } \\
\hline & & & & & & & alive & stillborn \\
\hline SDS & 10 & $56,6 \pm 7,5$ & $279,1 \pm 1,1$ & $29,7 \pm 0,7$ & $1,3 \pm 0,1$ & 70,0 & 10 & 0 \\
\hline $\begin{array}{c}\text { SDxCH } \\
\mathrm{H}\end{array}$ & 10 & $58,9 \pm 13,1$ & $280,5 \pm 1,1$ & $31,9 \pm 0,5$ & $1,4 \pm 0,1$ & 60,0 & 10 & 0 \\
\hline SSAS & 10 & $59,5 \pm 12,3$ & $281,4 \pm 1,1$ & $32,2 \pm 0,7$ & $1,4 \pm 0,1$ & 60,0 & 10 & 0 \\
\hline
\end{tabular}

Table 8. Economic efficiency of milk production in various genotypic groups of first-calf cows

\begin{tabular}{|c|c|c|}
\hline Group of animals & $\begin{array}{l}\text { Average milk yield of base fat milk } \\
\text { per 1 lactation, centner }\end{array}$ & $\begin{array}{l}\text { Cost of additionally produced milk } \\
\text { from a group of cows, rub. }\end{array}$ \\
\hline SDS & 35,1 & - \\
\hline SDxCHH & 36,7 & 14535,0 \\
\hline SSAS & 44,8 & 87188,0 \\
\hline
\end{tabular}

\section{Conclusion}

We have established the following as a research result:

- heifers in the SDxCHH genotypic group by 18 months of age $-345.5 \mathrm{~kg}$ on average and heifers in the SSAS group - $334 \mathrm{~kg}$ on average had the best live weight indicators;

- earliest age of the first insemination was noted in individuals of the SDxCHH group - 20.8 months on average, and the latest - in the SDS group - at 23.2 months;

- all experimental animals were assigned to the dairymeat type according to their exterior characteristics;

- best indicators of milk yield for the first lactation were observed in animals of the SSAS group - $4153.1 \mathrm{~kg}$ of natural fat milk, and the lowest indicators were recorded in the SDS group - $3226.9 \mathrm{~kg}$ of milk;

- highest indicators for milk fat content were in the SDS group - $3.78 \%$ on average, and the lowest $3.74 \%$ in the SDxCHH group;

- udder of the experimental first-calf cows meets the requirements of for machine milking suitability in terms of their morphological and functional characteristics;

- shortest service period was recorded in the SDS group - 56.6 days on average. This indicator was slightly higher in individuals of other experimental groups (by 2.3-2.9 days);

- in terms of the cost of additionally produced milk, first-calf cows in the SSAS group exceeded their counterparts by the amount of base fat milk from the other two genotypic groups by 14,535 - 87,188 rubles. We recommend the blood "refreshing" method to increase the milk productivity of domestic breeding cattle, that is, to inseminate the broodstock with the semen of breeding bulls of Austrian selection, being necessarily checked for the litter quality and having received a high breeding category.

\section{References}

1. M.D. Dedov, State and direction of breeding work with the Simmental and Sychevsk breeds of cattle, in: Methods for improving Simmental and Sychevsky cattle in the USSR (Kolos, Moscow, 1982) pp. 5-36.

2. E.I. Anisimova, L.V. Kononova, O.V. Sycheva, Pedigree resources of the Simmental cattle in the VIC "Abodimovskiy", Agricultural and food innovation, 3(7), 19-27 (2019)

3. S.A. Lamonov, Efficiency of using purebred and improved Simmental cows, Dairy and beef cattle breeding, 2, 15-16 (2009)

4. J. Stock, H. Esfandyari, D. Hinrichs, J. Bennewitz, Implementing a genomic rotational crossbreeding scheme to promote local dairy cattle breeds - A simulation study, Journal of Dairy Science, 104(6), 6873-6884 (2021)

5. S.A. Lamonov, S.F. Pogodaev, Simmentals improved with Holstein in a dairy complex, Zootekhniia, 1, 11 (2003)

6. N.I. Strekozov, Dairy farming in Russia: present and future, Zootekhniia, 1, 18-21 (2008)

7. M.-A. Magne, J. Quénon, Dairy crossbreeding challenges the French dairy cattle sociotechnical regime, Agronomy for Sustainable Development, 41(2), 25 (2021) 
8. L.K. Ernst, Livestock breeding and dairy complex, Rural life, 5, 2 (1980)

9. E. Karaman, G. Su, I. Croue, M.S. Lund, Genomic prediction using a reference population of multiple pure breeds and admixed individuals, Genetics Selection Evolution, 53(1), 46 (2021).
10. O.V. Gorelik, P.S. Galushina, I.V. Knysh, E.Yu. Bobkova, I.A. Grigoryants, Relationship between cow milk yield and milk quality indicators, IOP Conference Series: Earth and Environmental Science, 677(3), 032013 (2021). 